\title{
Llibres rebuts
}

Diàlegs. Revista d'Estudis Politics i Socials, 58 (2012). 112 p.

Letras de Deusto, 136 (2012). 298 p.

Letras de Deusto, 137 (2012). 322 p.

Veríssimo Serrão, Adriana (coord.) (2013). Filosofia e arquitectura da paisagem. Intervençôes. Lisboa: Centro de Filosofia da Universidade de Lisboa. 